\title{
Antropologia dźwięku wobec protestów społecznych i politycznych
}

\section{Abstract \\ Anthropology of Sound versus Social and Political Protests}

In the article I consider contemporary social and political protests from the perspective of anthropology of sound and/or sound studies. I do not focus on any series of specific protests or any single demonstration. I refer to these phenomena in a global perspective rather due to the universal specifics of their sound dimension. The soundness of contemporary protests is more than a matter of noisiness and in my opinion it undergoes significant global changes which can be link with changes in the technology of protesting. What I propose it is the anthropological reflection that goes beyond regular interpretations of protests, resistance or demonstrations.

The article is the presentation of selected concepts in the field of anthropology of sound, ethnomusicology, acoustic ecology, cultural poetics and theory of voice. Also I examine such categories as noise, voice, democratic soundscape, protest song, human microphone, wave of emotions, sophrosyne or social physics.

Keywords: anthropology of sound, voice, noise, human microphone, sounds of protests, democratic soundscape, wave, protest song.

W artykule przyglądam się współczesnym politycznym i społecznym protestom z perspektywy antropologii dźwięku, która łączy z sobą koncepcję z zakresu antropologii zmysłów, języka, głosu i poetyki z ekologią akustyczną, etnomuzykologią oraz sound studies. Tekst ma charakter przeglądowy i nie skupiam się w nim ani na serii konkretnych protestów ani na pojedynczej demonstracji. Odnoszę się do tych zjawisk w perspektywie globalnej ze względu na uniwersalną specyfikę ich dźwiękowego wymiaru. To, co proponuję, to nie tyle alternatywne spojrzenie na 
protesty, choć można byłoby tak sprawę postawić wobec niszowości antropologii dźwięku, ile spojrzenie, które warto rozważyć w sytuacji, gdy w naukach społecznych i humanistycznych dominuje refleksja nad wizualnością lub/i politycznością tych ekspresji społecznych.

Banałem jest stwierdzenie, że każdy protest odbywający się w przestrzeni publicznej ma znaczący wymiar dźwiękowy, a wymiar ten zawsze pozostaje polityczny. Szeroko rozumiany dźwięk jest używany strategicznie lub taktycznie niezależnie od tego, czy będzie to hałas czy cisza, muzyka popularna czy tradycyjna, śpiew czy skandowanie. Przy czym, mimo iż hałas jest pojęciem relatywnym i niejednoznacznym, to wśród dźwięków kojarzonych z protestami uznaje się go za posiadający w różnych kulturach szczególny wzorzec funkcjonowania, który pozwala na jego rozpatrywanie w kontekście oporu, kontestacji, subwersji i transgresji (Lichota 2016: 7-14). Niemniej jednak dźwiękowość współczesnych protestów to coś więcej niż kwestia hałaśliwości i w mojej ocenie przechodzi znaczące globalne zmiany, które łączą się ze zmianami technologii protestowania oraz normalizacją działań protestacyjnych.

Źródła mojego zainteresowania dźwiękowym aspektem protestów są właściwie trzy i to one bezpośrednio prowadzą mnie do podjęcia prezentowanej tu dyskusji. Po pierwsze, jako aktywna antropolożka dźwięku oraz field recordistka, od co najmniej 10 lat zajmuję się dźwiękową dokumentacją przestrzeni publicznych dużych polskich miast. Interesują mnie przede wszystkim zmiany możliwe do „notacji” z perspektywy dźwiękowej. Siłą rzeczy co jakiś czas rejestruję rozmaite publiczne zgromadzenia - strajki, procesje, manifestacje, pikiety, marsze, zbiegowiska, bójki, publiczne spontaniczne świętowania, ale również koncerty, happeningi, spektakle uliczne i festiwale. Prowadzę także badania dotyczące dźwiękowej kartografii oraz field recordingu. Są to zjawiska ściśle powiązane z rozwojem i upowszechnieniem mobilnych technologii usprawniających nagrywanie, edycję i dystrybucję nagrań terenowych. Od co najmniej dekady ten trend społeczny przejawia się $\mathrm{w}$ formie różnorodnych tematycznie internetowych map dźwiękowych. Wśród nich moją uwagę przykuły ostatnio mapy dźwiękowe powstające w ramach globalnego projektu Cities and Memory ${ }^{1}$, zapoczątkowanego przez brytyjskiego artystę dźwiękowego Stuarta Fowkesa. Jedną z map wchodzących w skład Cities and Memory jest ufundowana w 2017 roku globalna mapa protestów i demonstracji Protest \& Politics $^{2}$ inspirowana anty-Trumpowskimi protestami w USA (2016), antybrexito-

1 Ta globalna mapa dźwiękowa powstała w 2014 roku. Jej specyfika polega na tym, że powiązane z określoną lokalizacją dźwięki funkcjonują w dwóch wersjach - jako nagrania terenowe oraz ich remiksy i interpretacje. Cities and Memory to także kilkanaście tematycznych projektów-submap, takich jak na przykład „Prison Songs”, „Dada Sounds”, „Oblique Strategies” itd. https://citiesandmemory.com/ (dostęp: 30.07.2018).

2 https://citiesandmemory.com/protest/ (dostęp: 30.07.2018). 
wymi w Wielkiej Brytanii (2016-2017) oraz manifestacjami sprzeciwiającymi się polityce Frontu Narodowego ${ }^{3}$ Marine Le Pen we Francji (2017).

Po drugie dźwiękowy wymiar protestu, zwłaszcza w kontekście antropologii słuchania (Lawy 2017: 192-215), koncepcji głosu (np. Feld et al. 2004: 21-346; Schlichter 2011: 31-52; Weidman 2014: 37-51) i poetyki kulturowej (Feld 1982) interesuje mnie przez wzgląd na badania, jakie prowadzę wśród członków poznańskiego Chóru Czarownic. Badania te podjęłam na początku roku 2018 w ramach przygotowań referatu Singing Polish Witches - Women's Resistance and Protest against Everyday Injustice na coroczną konferencję Association of Social Anthropologists of the UK and Commonwealth ${ }^{4}$. Choć bezpośrednią inspiracją powstania tej grupy w 2016 roku była historia pierwszej kobiety w Polsce oskarżonej o czary i spalonej na stosie ${ }^{5}$, to z pewnych względów warto ją rozpatrywać w kontekście Czarnych Protestów oraz Ogólnopolskiego Strajku Kobiet. Sam chór narodził się w czasie warsztatów ze śpiewu białego w projekcie Aktywator - kultura dla przestrzeni, przestrzeń dla kultury ${ }^{6}$ i do momentu powstania pierwszych rebeliancko-feministycznych tekstów śpiewanych, krzyczanych i szeptanych przez chórzystki pozostawał raczej niewinnym przejawem wokalnej aktywności kobiet. W protest songach chóru manifestowana jest niezgoda na dyskryminację i wykorzystywanie ze względu na płeć. Utwory te dotykają ważnych, poruszanych przez współczesne feministki kwestii (szczególnie wyraźnie widać to w trakcie Czarnych Protestów), takich jak genderyzacja sfery publicznej i prywatnej, kulturowe oczekiwania wobec kobiet, ich cielesność i uprzedmiotowienie, historia prześladowania, problem przemocy oraz gwałtu. Jedna z pieśni chóru odegrała ważną rolę w czasie pierwszych Czarnych Protestów. Jest to pieśn zatytułowana Twoja władza i została odśpiewana między innymi 3 i 24 października 2016 roku w Poznaniu, stając się symbolicznym hymnem demonstracji w tym mieście (Mazur 2016). Została ona zaprezentowana nie tylko przez same chórzystki, ale także przez kobiety protestujące w Zielonej Górze (Rancew-Sikora, Steciąg 2017: 31; Nodzyńska 2018), Szczecinie (Sasinowski 2016), Warszawie (Demonstracja „Wol-

3 Używam tu nazwy partii, która obowiązywała do czerwca 2018 roku. W marcu 2018 r. przewodnicząca Marine Le Pen zaproponowała zmianę nazwy partii poprzez wewnętrzne referendum. Motywowała zmianę nazwy faktem, że nazwa Front Narodowy, którą partia nosi, odkąd została założona w 1972 r., dla wielu Francuzów stanowi barierę psychologiczną. 1 czerwca 2018 r. ogłosiła, że zmiana nazwy została zatwierdzona w wyniku referendum. Zob. Marine Le Pen annonce que le Front national devient Rassemblement national, „Le Monde”, 01.06.2018, https://www.lemonde. fr/politique/article/2018/06/01/marine-le-pen-annonce-que-le-front-national-devient-rassemblement-national_5308450_823448.html (dostęp: 30.07.2018).

4 https://www.anthro.ox.ac.uk/asa-2018 (dostęp: 30.07.2018).

5 Pierwszy publiczny performance Chóru Czarownic, pt. Czarownica z Chwaliszewa, odbył się w maju przed Teatrem Polskim w Poznaniu na zakończenie festiwalu teatralnego Bliscy nieznajomi, http://kultura.poznan.pl/mim/kultura/news/relacje-recenzje-opinie,c,9/bliscy-nieznajomi-gloschoru, 106073.html (dostęp: 30.07.2018).

${ }^{6}$ http://www.inspirator-polska.pl/aktywator-kultura-poznan/ (dostęp: 30.07.2018). 
ne Polki - Wolna Polska" 2017; Wieczorkiewicz 2018), Tomaszowie Mazowieckim (Sztymelska 2017), Olsztynie ${ }^{7}$ i Berlinie ${ }^{8}$. Rebelianckość Chóru Czarownic jest bardzo często podkreślana w artykułach prasowych i recenzjach, których autorki i autorzy piszą choćby o „donośnym głosie polskich kobiet”, ich „buntowniczym charakterze”, „feministycznym arsenale”, „kobiecej rebelii” czy „odzyskanym głosie" (Bartosiewicz 2017; Bednarz 2017; Dłużewska 2017; Drajewski 2017; Jaśkiewicz 2017; Marzec 2017; Misiakiewicz 2017; Pezda 2017; Tyszka 2017; Doroszkiewicz 2018; Żmijewska 2018). I to właśnie kwestia głosu oraz jego słyszalności interesuje mnie najbardziej w kontekście prowadzonych przeze mnie badań.

Po trzecie, od pewnego czasu śledzę wzmożone zainteresowanie badaczy społecznych różnorodnymi formami protestów i manifestacji społecznych oraz politycznych, które akurat w ramach globalnie ujętej antropologii zintensyfikowały się wraz z Arabską Wiosną (np. „American Ethnologist” 2012; Fosshagen 2014; „Visual Anthropology” 2016), Euromajdanem („American Ethnologist” 2014), Ruchem Occupy (Juris, Razsa 2012), by zyskać na rozkwicie wraz z protestami związanymi z wyborem na prezydenta USA Donalda Trumpa (np. „American Ethnologist” 2017; „Anthropology Now” 2017; Stoller 2016, 2017) $)^{9}$ oraz brexitem (np. „American Ethnologist” 2017; „Social Anthropology” 2016). Antropologiczna refleksja nad protestami nie ogranicza się oczywiście wyłącznie do wyżej wymienionych. To także choćby analiza protestów studenckich na francuskich, greckich czy kanadyjskich uniwersytetach (Thorkelson 2016; Yiakoumaki 2011), fali samopodpaleń wśród Tybetańczyków (Makley 2015), protestów i zamieszek w Turcji (Yıldırım, Navaro-Yashin 2013) czy protestów miejskich w Brazylii (Holston 2013) w 2013 roku, protestów międzynarodowego ruchu \#BlackLivesMatter (np. Furmage, Rubin 2015). W roku 2013 powstała platforma internetowa The Resistance Studies Network dedykowana badaczom zajmującym się praktykami opo$\mathrm{ru}^{10}$. W jej ramach od 2015 roku wydawane jest czasopismo „Journal of Resistance Studies"11, w którym publikowane są artykuły dotyczące przejawów szeroko rozumianego oporu oraz metodologii studiów nad nim (np. Baaz, Lilja, Vinthagen 2017; Koefood 2017).

W polskim kontekście zainteresowanie manifestacjami i oporem, a wraz z tymi zjawiskami nowymi ruchami społecznymi i politycznymi, wiąże się z falami protestów społecznych rozpoczętych w roku 2016 (m.in. protesty Komitetu Obrony

7 https://www.facebook.com/events/968921066552964/?active_tab=discussion (dostęp: 30.07.2018).

8 https://www.facebook.com/events/1666165643698900/?active_tab=discussion (dostęp 30.07.2018).

9 Warto nadmienić, że w ramach amerykańskiej antropologii funkcjonuje nawet sformułowanie „anthropology of Trump”, a czasopismo „Cultural Anthropology”, zwłaszcza w ramach „Fieldsights”, od 2016 r. systematycznie publikuje artykuły, eseje, felietony, komentarze dotyczące polityki Donalda Trumpa oraz ruchu anty-Trumpowskiego.

10 http://resistancestudies.org/ (dostęp: 30.07.2018).

11 http://resistance-journal.org/ (dostęp: 30.07.2018). 
Demokracji, Ogólnopolski Strajk Kobiet, poznańskie „łańcuchy światła”). Ma ono jednak charakter mniej akademicki, a bardziej popularnonaukowy, krytycznodziennikarski ${ }^{12}$ i w dużej mierze artystyczny, znajdując swój wyraz w sztuce zaangażowanej społecznie (na wystawach ${ }^{13}$, happeningach ${ }^{14} \mathrm{i}$ warsztatach ${ }^{15}$ ).

Agnieszka Pasieka we wstępie do wydanej w 2015 roku antologii tekstów Opór $i$ dominacja porusza kwestię raczej niewielkiego i specyficznego podejścia do pojęcia oporu w literaturze polskojęzycznej (Pasieka 2015: 22), które zastępowane jest często innymi, takimi jak kontestacja (Maślanka, Wiśniewski 2015) czy bunt (Kuligowski, Pomieciński 2012), a także wskazuje na częste łączenie tego pojęcia z ruchami alterglobalistycznymi czy marszami równości (Pasieka 2015: 23). Polskie resistance studies wydają się dopiero na początku drogi. I tak do tekstów naukowych zaliczyłabym artykuły opublikowane w czasopiśmie „Czas Kultury”, którego jeden z numerów z roku 2017 w części został poświęcony aktualnym manifestacjom obywatelskim w Polsce. Są to teksty autorstwa wyłącznie socjologów i socjolożek, którzy na łamach tego czasopisma prowadzą zalążkowe analizy roli manifestacji w polskiej kulturze politycznej (Podemski 2017: 6-11), dyskursów społeczno-politycznych w sytuacji kryzysów i napięć społecznych (Nowicka-Franczak 2017: 12-20), proponują metodologię badań nad protestami (Drozdowski 2017: 21-26), wykorzystują koncepcję karnawału w interpretacji strajku kobiet w Zielonej Górze (Rancew-Sikora, Steciąg 2017: 27-34), dyskutują nad znaczeniem artefaktów używanych w trakcie protestów (Ślosarski 2017:

12 Wiele krytycznych analiz opublikowanych zostało m.in. na łamach „OKO Press” (Graff, Korolczuk 2016), „Krytyki Politycznej” (np. Kubisa 2016; Sutkowski 2017; Korolczuk 2018), „Visegrad Insight” (Grzebalska 2016), „openDemocracy” (Narkowicz 2016) czy „Gazety Wyborczej” (Leniarska 2016; Mazur 2016; Wodecka 2016).

13 Na przykład towarzyszące protestom i manifestacjom z okazji Dnia Kobiet w 2017 r. wystawa Kobiety, które siedzq w Łodzi / manifest obecności grupy Frakcja w łódzkiej Galerii Manhattan Transfer, wystawy Złe kobiety w Centrum Kultury „Zamek” w Poznaniu czy wystawa Polki, patriotki, rebeliantki, prezentowana w Galerii Miejskiej „Arsenał” we wrześniu i październiku 2017 r.

14 Na szczególną uwagę zasługują działania towarzyszące warszawskim pikietom i marszom zorganizowanym w ramach Ogólnopolskiego Strajku Kobiet z okazji Dnia Kobiet, takie jak: akcja malowania graffiti Ściana Furii - chodźmy coś zmalować, czytanie utworów dotyczących praw reprodukcyjnych Feministyczne Czytanki, happening Kwiaty Polskie - podziękowania dla Parlamentu, życzenia okolicznościowe dla Beaty Szydło przed Kancelarią Premiera, akcja Pomachajmy biskupom na pożegnanie!, happeningi Blondynki wywoluja polityków i Niebieska Linia czy Freedom disco.

15 Na przykład: cykl warsztatów STRAJK. Haft okupacyjny w Bunkrze Sztuki w Krakowie w 2017 r., podczas których uczestniczki własnoręcznie przygotowywały transparenty na manifestację 8 marca 2017 r.; warsztaty To mnie wkurza, czyli sztuka buntu dla opornych przeznaczone dla młodych dziewcząt, towarzyszące wystawie Polki, patriotki, rebeliantki; warsztaty dźwiękowe w ramach rezydencji Donii Jourabchi oraz Davide’a Tidoniego zaproszonych do Centrum Sztuki Współczesnej „Zamek Ujazdowski” w czerwcu i lipcu 2017 r., którzy zajęli się zagadnieniem projektowania akustycznego demonstracji; warsztat-impreza Protest Song Karaoke w przestrzeni wystawy Gotong Royong. Rzeczy, które robimy razem; warsztaty Edyty Jarząbek Głos sprzeciwu w Teatrze Powszechnym w Warszawie. 
35-41), ruchem obywatelskim tzw. obrońców krzyża (Krzemiński 2017: 42-49) czy przestrzenią architektoniczną dla protestów (Kowalewski 2017: 50-64). Jednym $\mathrm{z}$ nielicznych polskojęzycznych tekstów antropologicznych jest utrzymany w nurcie antropologii politycznej artykuł Wojciecha Dohnala „Czarny poniedziatek” $i$ "Eańcuch światta”. O infrapolitycznych formach oporu społecznego (2017). Artykuły naukowe dotyczące bieżących manifestacji obywatelskich, w tym przede wszystkim Czarnych Protestów, można odnaleźć także w takich czasopismach, jak „Balitc Worlds” (Korolczuk 2016; Karlberg 2017: 4-9) czy „Praktyka Teoretyczna” (Majewska 2016). Warto tu wskazać także na raport Rewolucja - i co dalej? Ruchy kobiece w poszukiwaniu nowych form polityczności z 2017 roku pod redakcją socjolożki Agaty Czarneckiej, w którym znajdziemy analizy polityczek, dziennikarek, aktywistek pozarządowych oraz akademiczek. Wreszcie ogólnopolskie protesty obywatelskie stały się inspiracją dla wielu debat publicznych czy seminariów naukowych ${ }^{16}$.

Tym, co jednak z przyjętej przeze mnie perspektywy pozostaje najistotniejsze i najbardziej frapujące, jest fakt, że coraz częściej dostrzegany jest również kontekst dźwiękowy protestów. W Polsce zajmują się nim badacze i artyści dźwięku publikujący na łamach czasopisma „Glissando". O fonosferze protestów traktuje choćby test poświęcony akustycznemu obliczu sprzeciwu wobec PRL-u (Michnik 2011), soundscape’owi Majdanu (Morozova 2015), hałasowi wokół inwazji na Czechosłowację w 1968 roku (Borowska 2017) czy projektowaniu akustycznemu manifestacji i koncepcji głosu (Jarząb 2017a, 2017b). O wymiarze dźwiękowym polskich protestów piszą pokrótce Dorota Rancew-Sikora oraz Magdalena Steciąg w artykule „Niech się bawiq"? O związkach radykalności z karnawałem na demonstracjach publicznych kobiet (2017), w którym analizują kinestetykę Strajku Kobiet 8 marca 2017 roku w Zielonej Górze. Jeden z akapitów artykułu poświęcają prozodii protest songu Chóru Czarownic Twoja władza oraz ogólnej hałaśliwości tej manifestacji przejawiającej się w powtarzalnej emisji dźwięków piosenek popkulturowych, użyciu trąbek, kołatek, łapek do klaskania, gwizdach, mocnym i dobrze nagłośnionym, typowym dla wystąpień podczas protestów ulicznych, przekazie werbalnym.

Zagadnienie dźwiękowego wymiaru polskich protestów to także domena działań i refleksji o charakterze artystycznym. Przykładowo w roku 2016 w ramach programu rezydencyjnego Sound of Culture - Culture of Sound ${ }^{17} \mathrm{w}$ Centrum Sztu-

16 Czarny Protest - perspektywa ruchów społecznych i teorie oporu - seminarium z cyklu Gender i seksualność w polskiej nauce i praktyce społecznej zorganizowane przez IFiS PAN w 2017 r.; Polityka protestu i performatyka oporu zorganizowana przez warszawski oddział partii Razem; cykl spotkań Performatyka Protestu zorganizowany przez Biennale Warszawa między marcem a czerwcem 2017 r.; sesje dyskusyjne towarzyszące wystawie Polki, Patriotki, Rebeliantki w Galerii Miejskiej „Arsenał” w Poznaniu w 2017 r.; program dyskursywny towarzyszący wystawie Gotong Royong. Rzeczy, które robimy razem $\mathrm{w}$ CSW w Warszawie.

${ }_{17}$ Jest to europejska sieć rezydencji artystycznych oparta na współpracy m.in. takich ośrodków jak Q-O2 (Belgia), Binaural/Nodar (Portugalia), HAI ART (Finlandia), DISK (Niemcy). Celem 
ki Współczesnej „Zamek Ujazdowski” artyści dźwiękowi Donia Jourabchi oraz Davide Tidoni podjęli się badań nad politycznym i ekologicznym wymiarem dźwięku w Warszawie. W roku tym jednym z najbardziej dynamicznych i charakterystycznych elementów pejzażu dźwiękowego miasta stały się brzmienia protestów i demonstracji politycznych, a działania artystów skoncentrowały się na projektowaniu dźwięków demonstracji. Dźwięk został w tym wypadku ujęty jako narzędzie, za pomocą którego obywatele mogą wyrażać swe racje polityczne i upominać się o swoje prawa. Rezydenci badali nowe strategie protestowania za pomocą dźwięku: organizowali warsztaty, prowadzili obserwacje, tworzyli improwizowane interwencje dźwiękowe oraz brali czynny udział w demonstracjach. Refleksja nad politycznym aktywizmem i politycznością dźwięku została podsumowana również $\mathrm{w}$ dwujęzycznej publikacji Warsound/Warszawa (2016) zawierającej artykuły, których autorzy tworzą pomosty między filozofią a ekologią akustyczną, sztuką dźwięku a protestem, technologiami dźwięku a ruchami oporu. Choć teksty odnoszą się do koncepcji dźwięku protestów jako pola bitwy wypełnionego pomrukami władzy i emanującego przemocą akustyczną, to ich główne założenia dotyczą wspólnotowości i solidarności możliwych do osiągnięcia poprzez dźwięk, który przełamuje izolację i wykluczenie społeczne.

W jaki sposób jednak dźwięk można uwzględniać w badaniach i analizach nad protestami rozumianymi jako ekspresywny i publiczny wyraz oporu społecznego? Zastosowanie „klasycznej” antropologii dźwięków lat 80. i 90. XX wieku bywa problematyczne w odniesieniu do miejskich i zachodnich kontekstów społecznokulturowych przede wszystkim dlatego, że subdyscyplina ta wyrasta $\mathrm{z}$ fascynacji pozaeuropejskimi środowiskami akustycznymi i zadaje pytania o miejsce dźwięku w całych systemach kulturowych. Oczywiście refleksja nad relacją między dźwiękiem a kulturą ma w antropologii znacznie dłużą tradycję. Wystarczy nadmienić pionierskie badania Franza Boasa nad sound-blindness (1889: 47-54) czy homologię mitu i muzyki Claudea Lévi-Straussa w The Raw and the Cooked (1970). Niemniej dźwięku nie rozpoznawano jako odrębnego przedmiotu badań aż do końca XX wieku. Steven Feld jako pierwszy określił swoją pracę jako antropologię dźwięku w roku 1980 w nawiązaniu do badań, jakie prowadził wśród społeczności Kaluli w Papui-Nowej Gwinei. To na ich podstawie stworzył metodologię pozwalającą na fenomenologiczne i środowiskowe poprowadzenie badań etnograficznych nad dźwiękiem (Feld 1996: 91-136). Sposób Felda jest jednak specyficzny, ponieważ sięga on po poetykę, literaturę parajęzykową i prozodyczną, eseje dotyczące systemów dźwiękowych, symbolizmu fonetycznego oraz koncepcji takich klasyków jak Franz Boas (1940), Roman Jakobson (1987) czy Edward Sapir (1949). Inspirował się również koncepcją soundscape’u R. Murraya Schafera, która dziś uznawana jest za co najmniej kłopotliwą. Schafer sprecyzował soundscape

projektu jest mobilność młodych artystów, kuratorów i badaczy sztuki dźwięku, którzy w ramach rezydencji w różnych ośrodkach w Europie podejmują działania mające na celu zaangażowanie publiczności w kreatywne działania, których tworzywem są dźwięk i środowisko dźwiękowe. 
jako soniczną wersję krajobrazu oraz szczególny przedmiot ludzkiej kontemplacji (Schafer 1977). Jednakże ze swojej koncepcji niemal całkowicie wykluczył „hałas". Ta wręcz romantyczna wizja przestrzeni akustycznej wydaje się trudna do zastosowania w kontekście współczesnych stechnologizowanych i mobilnych krajobrazów kulturowych. Słabość pojęcia pejzażu dźwiękowego sygnalizuje między innymi Tim Ingold, uznając je za pojęcie uprzedmiatawiające dźwięk oraz nadające percepcji słuchowej niemożliwą wręcz do osiągnięcia autonomię. Dla tego badacza percepcja rzeczywistości poprzez dźwięk to okazja do jej immersyjnego odczuwania (Ingold 2007: 10-13, 2011: 136-139). Pewne uzupełnienie względem tej idei proponuje Stefan Helmreich (2010: 10), wskazując na transdukcję jako pojęcie ożywiające refleksję nad współczesnymi mechanizmami wytwarzania przestrzeni.

Antropologia dźwięku wyłoniła się jako subdyscyplina łącząca koncepcję dźwięku jako systemu symbolicznego z kulturową poetyką, semiotyką, antropologią lingwistyczną, studiami nad mową, werbalnością oraz performance’em. Nadal pozostaje silnie powiązana $\mathrm{z}$ rozwijającą się $\mathrm{w}$ latach 90 . XX wieku antropologią zmysłów (Howes 1991), kiedy to po wcześniejszych dyskusjach, charakteryzujących choćby antropologię osoby i emocji, w końcu pojawiło się zainteresowanie kulturowym aspektem percepcji. Począwszy od krytyki zachodniego wizualizmu (Classen 1993; Stoller 1989), antropolodzy skupili się na alternatywnych sposobach odczuwania i rozumienia świata. Międzykulturowe studium metaforycznego języka zmysłów ujawniło, że w różnych kulturach zmysł słuchu jest nie tylko symboliczny, ale również powiązany z zachowaniem. „Usłyszeć” oznacza „zrozumieć”, „działać poprawnie”, „być posłusznym”, a ludzie, którzy „nie słyszą”, znajdują się na granicy tego, co społeczne i kulturowe (Classen 1993; Reichel-Dolmatoff 1971). Jeśli słuch wraz $\mathrm{z}$ innymi zmysłami jest uporządkowany odmiennie w różnych kulturach, to każda dyskusja o dźwięku powinna rozpocząć się od analizy kulturowego znaczenia zmysłów i porządku zmysłowego w określonym społeczeństwie. Te kulturowe znaczenia słyszenia możliwe są do identyfikacji poprzez analizę tego, w jaki sposób zmysły są opisywane w języku, ich metaforyczne zastosowania, czynności rytualne wykonywane w celu ich usprawnienia lub kontrolowania. Metafory, które wykorzystują zmysł słuchu, mogą być przydatnymi instrumentami do analizy powiązań ekspresji kulturowych z wykonawstwem władzy politycznej lub z oporem i buntem przeciwko niej.

Studia nad językiem i głosem, przestrzenią i miejscem, ciałem i zmysłami, muzyką i kulturą ekspresywną współcześnie niemal zawsze uwzględniają aspekt dźwiękowy. Ten zwrot jest wyraźny w wielu akademickich projektach (Novak, Sakakeeny 2015: 6-7). Tematyczne ramy studiów nad muzyką, a więc skupione na stylu, repertuarze oraz estetyce, zostały zakwestionowane przez badaczy z nurtu szeroko rozumianych sound studies. Przykładem mogą być prace Davida Suismana i Susan Strasser (2009), Marka Katza (2010), Jonathana Sterne'a (2012) i innych, którzy poruszają zagadnienia produkcji i konsumpcji muzyki oraz ukazują, 
w jaki sposób proces zapośredniczenia dźwięku warunkuje jego odbiór i ogólną auralność współczesności. Podobnie zbiory tekstów, redagowane przez Georginę Born (2013), Michaela Bulla (2013), Sumanth Gopinath i Jasona Stanyeka (2014), dotyczą społecznego aspektu wytwarzania oraz rozpowszechniania muzyki. To zaś okazuje się dobrym tropem dla analizy dźwiękowego wymiaru protestów.

Dźwięk i słyszenie są powiązane z ustalaniem i negocjowaniem porządku społecznego. Zagadnienie to zostało opisane przez antropologów i historyków niekoniecznie bezpośrednio zainteresowanych dźwiękiem. Wspomniany już Claude Lévi-Strauss, wskazując na opozycję między hałasem i ciszą w rytuale i mitologii, zaproponował ogólny model interpretacji intencjonalnego wytwarzania hałasu jako sposobu rozwiązywania problemów społecznych i konfliktów, a następnie przywracania porządku (Lévi-Strauss 1970: 147-150, 286-289, 327-330; 1973: 359-475). Zwróćmy uwagę na znaczenie hałasu w europejskich rytuałach charivari (Davis 1973: 41-75), Katzenmusik (Darnton 1991) i rough music (Thompson 1991: 467-538) czy w rytuałach kontroli społecznej (Pitt-Rivers 1961); dalej, na używanie instrumentów i przedmiotów wytwarzających hałas w życiu wspólnotowym (religijnym i świeckim) w Europie choćby w okresie karnawału (Corbin 1995; Mintz 1997: 145-148). Wiele innych koncepcji powiązanych z dźwiękiem, takich jak cisza czy głos, dotyczy z kolei doświadczenia. Słysząca osoba jest tu rozpoznawana jako podmiotowa, a „posiadanie głosu” sugeruje więcej niż umiejętność mówienia czy śpiewania. Jako semantyczny przedmiot języka, a także jako odczuwane zjawisko percepcyjne dźwięk wraz koncepcjami ekspresji kulturowej, cielesności i partycypacji ujawnia tożsamości publiczne i polityczne (Erlmann 2004: 1-20).

Jedną z bardziej interesujących teorii z zakresu antropologii dźwięku, która dotyczy kultury politycznej, w tym protestów, oporu i rebelii, jest teoria Stefana Helmreicha, który przenosi fizyczne koncepcje fal grawitacyjnych i akustycznych na kontekst społeczny (2016: 464-492). Badacz ten używa tego zabiegu w swojej analizie intensyfikacji anty-Trumpowskich protestów w USA, wyrażającej się $\mathrm{w}$ stosowaniu pojęcia fali w mediach publicznych (np. fale populizmu, nacjonalistycznych sentymentów, niepokojów ekonomicznych, katolicyzmu, złości białych wyborców, przestępstw z nienawiści) (Molina, Cossette 2016). Sformułowania takie $\mathrm{z}$ łatwością można odnaleźć także w polskojęzycznej prasie, zwłaszcza w nagłówkach artykułów dotyczących protestów i manifestacji eskalujących w przestrzeni publicznej w ciągu ostatnich dwóch lat: Lekarze: będzie fala protestów, minister zdrowia nas zlekceważyl; Fala protestów w Polsce; Fala protestów w kraju przybiera na sile; Kobiety przeciw, czyli fala protestów; Fala protestów przeciwko upartyjnianiu sądów; Nowa fala czarnych protestów; Czarny Protest nie tylko $w$ Polsce. Ta fala obejmuje kolejne państwa. Według Stefana Helmreicha użycie tego pojęcia to próba uchwycenia znajdujących się w ruchu, dynamicznych emocji i sentymentów społecznych (Molina, Cossette 2016). Oczywiście jako koncepcja fizyczna fala w opisie socjologicznym wymaga innego podejścia. Nie jest to tak- 
że nowa kategoria naukowa stosowana przecież przy okazji analiz transformacji społecznych. W teoriach antropologicznych można ją odnaleźć u Nancy Hewitt piszącej o falach feminizmu (2010), Davida Graebera rozważającego o powstańczych falach oporu na przykładzie Ruchu Occupy czy Arabskiej Wiosny (2013: $64,108)$.

Zastosowanie tej koncepcji wymaga jednak postawienia pytania o jej przyczynowość, zatem o to, kto lub co wywołuje fale w sensie fizycznym i afektywnym; czy są formowane przez struktury historyczne i tworzą ramy dla działań społecznych; czy są ekspresją materializującej się kolektywnej sprawczości. Równie istotne jest dotarcie do mechanizmów, które decydują o tym, że fale zyskują status reprezentacji społecznych i politycznych, a także zwrócenie uwagi na to, że jako wyraz wspólnotowej mobilizacji nigdy nie są pojedyncze czy jednorodne. Wchodzą w relacje z kontrfalami, są zróżnicowane - wzajemnie się wzmacniają lub znoszą, nie zawsze są zsynchronizowane, czasem rezonują nieoczekiwanie z innymi, a gdy stają się wyrazem zbyt wielu postulatów naraz, mogą zostać zniesione lub przeminąć niezauważone (Molina, Cossette 2016).

Co to znaczy „fale emocji” i jak one brzmią? Czy możemy monitorować ruchy społeczne na poziomie dźwiękowym? W jaki sposób prowadzić badania nad dźwiękowym wymiarem protestów? Jeśli astronomowie słuchają fal grawitacyjnych poprzez interferometry, to jakim narzędziem powinniśmy posłużyć się jako badacze społeczni, by usłyszeć i zrozumieć fale protestów? Czy w ogóle istnieje jedna właściwa antropologia krytyczna, która pozwoli na takie słuchanie? Nawet jeśli antropolodzy i inni badacze społeczni słuchają, to czy wiemy, co słyszymy? Tak jak w przypadku obaw astronomów przed pomyleniem fal grawitacyjnych $\mathrm{z}$ innymi wibracjami pochodzącymi z kosmosu, tak samo antropolodzy powinni uważać na to, co uznają za sygnał (Molina, Cossette 2016).

Przykładów analiz i interpretacji (nie tylko naukowych) protestów i oporu z perspektywy dźwiękowej jest wiele. Odróżnienie sygnału od hałasu nie jest jednak proste. W świadomym słuchaniu zgromadzeń może pomóc uwzględnienie stwierdzenia Judith Butler na temat działań związanych z oporem, które nigdy nie są ani do końca dyskursywne ani predyskursywne (Butler 2015: 8), a także odrzucenie założenia o progresywności polityki zgromadzeń. Należy także uwzględniać sposoby zapośredniczania dźwiękowego wymiaru protestów przez media. Wymiar ten pojawia się w radiu, telewizji i internecie w różnej formie - jako fragmenty, streamingowane całości, wyedytowane nagrania terenowe czy kompozycje muzyczne. James Deaville, odwołując się do tektu Pierre’a Bourdieu On Television (1998), pokazuje, w jaki sposób od czasu wojny wietnamskiej zmieniała się forma medialnej (auto)prezentacji protestujących obywateli amerykańskich, którzy w szczególny sposób wzmacniają soniczny przekaz i kolektywną wokalność (Deaville 2011). Jednakże w momencie, kiedy dźwiękowy wymiar protestów przedostaje się do mediów, zyskując tym samym globalny charakter, to staje się podatny na manipulacje, wyciszenie, zniesienie i zniekształcenie. Słuchanie protestów nie 
oznacza więc tylko rejestracji i późniejszej analizy ich akustycznej zawartości. Wymaga prześledzenia jej recepcji i dystrybucji, dotarcia do tych nisz, w których dźwięk protestu odnosi różny skutek. Dźwiękowe strategie zawsze są wzmacniane, dzięki czemu stają się opozycyjne wobec powszechnej amplifikacji rasizmu, mizoginii, walki klasowej czy populizmu. Wedle Stefana Helmreicha jako zaangażowani obywatele jesteśmy zobowiązani do wytwarzania efektywnego hałasu, a więc dźwięku, który będzie nie tylko głośny, ale także wyartykułowany i zdolny do rewerbacji (Molina, Cossette 2016).

Hałas z pewnością jest jedną z kluczowych kategorii w badaniach nad dźwiękowym wymiarem protestów. Choć jego rozumienie jest zróżnicowane historycznie i kulturowo, a w wielu językach w ogóle nie rozróżnia się go jako określonej kategorii „dźwięe”, to powszechnie jest kojarzony z publiczną socjalnością, karnawałami, protestami etc. Jego zadaniem jest wprowadzenie niepokoju i podważenie norm życia codziennego. Jest też dźwiękiem, który należy rozpatrywać $\mathrm{w}$ odniesieniu do industrializacji i mechanizacji, bo w tym sensie jest rozpoznawany jako antyspołeczny efekt technologii, a więc coś przypadkowego i bez znaczenia (Novak, Sakakeeny 2015: 1-11). Według Davida Novaka hałas nie jest określonym rodzajem dźwięku, ale raczej metadyskursem nad dźwiękiem, kwestią jego społecznej i kulturowej interpretacji (Novak 2015: 125-138). Choć w postkolonialnych, multikulturowych i kosmopolitycznych społeczeństwach zachował status wyznacznika różnicy (Smith 1999; Picker 2003; Schwartz 2011), to bywa skutecznym narzędziem sprawczości grup mniejszościowych. Dźwięki wywołują poczucie inkluzji lub ekskluzji - wprowadzają więc podział na nas i innych, ugruntowują segregację w terminach lokalności, autentyczności, przynależności i narodowości (Pistrick, Cyril 2013: 1-11). We współczesnych projektach oporu hałas jest głosem podporządkowanych i marginalizowanych tożsamości. Robienie hałasu nie jest przypadkowe. Jest praktyką ekspresywną oraz intencjonalnym aktem subwersywnym (Rose 1994; Reynolds 2007; McCaugan, Balance 2009). I tak Jonathan Sterne pisze o protestach studenckich w Montrealu w 2012 roku w kontekście rough music, sugerując, że kakofoniczny tłum może artykułować społecznościowy opór skierowany przeciw opresji (Schulze 2012). O tych samych demonstracjach rozważa Maksymilian Kapelański, odwołując się do casseroles - fenomenu dźwiękowego wywodzącego się pierwotnie ze średniowiecznej Europy. Znany pod nazwą charivari stanowił wyraz moralnego werdyktu społeczności oraz karnawałowej zabawy będącej jednocześnie wybrykiem i kontestacją obowiązujących zasad (Kapelański 2015: 18-28).

Konca Sahera i Murat Cetina w Music and Performance as Sonic Acts of Political Struggle (2016: 378-391) przyglądają się relacji między władzą a dźwiękiem rozumianym jako narzędzie polityczne. Protesty są polem dźwiękowej walki przejawiającej się nie tylko w procesie zderzania ze sobą rozmaitych hałasów i szumów, amplifikacji i zwielokrotnianiu ludzkich głosów (Jurgenson 2011), ale także w regulacjach prawnych odnoszących się do technologii nagłośnienia czy 
nawet w przypadkach zastosowania broni sonicznej, takiej jak LRAD (Long Rang Acoustic Device $)^{18}$. Udźwiękawianie protestów jest też sposobem na zarządzanie tłumem. Hałas generowany przez gwizdy, krzyki, przeszkadzajki, klaksony, fajerwerki, śpiew i skandowanie jest konieczny do podtrzymania synergii i spójności publicznych protestów. Od strategicznego użycia ciszy po oklaski, nucenie sloganów, rytmiczne uderzenia w bębny bywa wyrazem albo aktu partycypacji i solidarności albo groźby.

Rozwój technologii dźwięku, która umożliwiła akustyczne wzmocnienie głosu w sferze publicznej, spowodował, że słyszalność stała się aspektem władzy, a wytwarzanie dźwięków narzędziem oporu wobec niej (Attali 1985), czego najlepszym przykładem jest użycie jego wysublimowanej formy, jaką jest muzyka narzędzie sprzeciwu i deklaracji światopoglądowych. Socjolodzy ruchów społecznych w USA, tacy jak Willam Roy (2010), Serge Denisoff (1970: 807-823), Ron Eyerman i Andrew Jamison, choć wskazują na istotną rolę muzyki protestów w kontekście wczesnych ruchów politycznych w USA, to udowadniają, iż współcześnie nie ma już takiej mocy jak dawniej. Obniżenie jej rangi to konsekwencja hegemonicznego charakteru branży muzyki komercyjnej, ogólnospołecznego oporu wobec partycypacji muzycznej, a także odizolowujących technologii konsumpcji muzyki, takich jak choćby słuchanie na słuchawkach (Eyerman, Jamison 1998). Mimo to muzyka nadal jest obecna na protestach. Etnomuzykolog Michael S. O’Brian w ciągu sześciu miesięcy w 2011 roku był świadkiem wielu przypadków tworzenia i wykonywania muzyki służącej politycznemu protestowi w nurcie $\mathrm{Ru}$ chu Occupy w Wisconsin. W artykule This is What Democracy Sounds Like (2013) studiuje sposoby odtwarzania, zapośredniczania i remediowania soundscape'ów innych, historycznych już protestów, co - jak się okazuje - nie tylko pobudza wyobraźnię protestujących, zagrzewa ich do utrzymywania oporu i sprzeciwu, ale również tworzy nowe aktualne polityczne tożsamości. Technologie nagrywania oraz masowego rozprzestrzeniania dźwięku (zwłaszcza w mediach społecznościowych) ani nie wykluczają, ani nie zastępują wykonań muzyki na żywo, raczej je odzwierciedlają i uzupełniają (O’Brien 2013).

Rok 2011 był wyjątkowy w USA pod względem skali protestów społecznych i politycznych. Protesty Ruchu Occupy były pierwszymi tak masowymi i intensywnymi po protestach przeciw wojnie w Wietnamie. Seria demonstracji o charakterze okupacyjnym rozpoczętych 17 września 2011 roku w Zuccotti Park

18 LRAD to urządzenie wytwarzające dźwięk o bardzo wysokiej głośności, który jest słyszalny na dużych odległościach. Jego głównym celem jest emitowanie fal dźwiękowych, które mają wywoływać u odbiorcy nieprzyjemną reakcję i wpływać na jego zachowanie poprzez odstraszanie. Zostało wyprodukowane i wprowadzone do użycia w 2000 w USA. Początkowo miało być używane na okrętach w celu ostrzegania przed zbliżaniem się bez pozwolenia innych statków. Bywa też używane do rozpraszania manifestacji i zgromadzeń przez siły policyjne. Jednakże jego użycie budzi kontrowersje, ponieważ może prowadzić do uszkodzenia słuchu. Ponadto jego skuteczność jest wysoce dyskusyjna ze względu na proste środki, które pozwalają uniknąć negatywnego działania LRAD (np. słuchawki ochronne). 
w Nowym Jorku została zainicjowana przez kanadyjską grupę aktywistów z organizacji AdBusters. Uczestnicy tych zgromadzeń, nazywający siebie „99 percenters", protestowali głównie przeciwko nierównościom społecznym, chciwości korporacji i banków oraz przeciwko nadmiernemu wpływowi bankierów, menedżerów wielkich korporacji i lobbystów na rząd. Te protesty zasłynęły przede wszystkim użyciem human/people microphone, który należy rozpatrywać nie tylko jako sposób na amplifikację skandowanych haseł, ale także jako wyraz solidarności protestujących. Jako forma mówienia i przemawiania posiadająca efekt muzyczny stał się emblematyczny dla bezkompromisowego idealizmu Ruchu Occupy. Jeremy Woodruff dookreśla human microphone, odwołując się do pojęcia tonalności społecznej formułującej się na zasadzie sprzężenia między przestrzenią, treścią wydarzenia a jego uczestnikami (Woodruff 2014: 17-20). Z kolei Katherine Kelp-Stebbins oraz Alison M. Schifani uważają, że human microphone to szczególna taktyka dźwiękowa, w której ciało staje się technologią. Taktyka ta związuje w nowy sposób sferę publiczną z biotechnologicznym potencjałem, destabilizuje pojęcie natychmiastowej komunikacji, która cechuje neoliberalną globalną ekonomię. Responsywny i analogowy charakter human microphne powoduje, iż protestujący jako niezasilany wzmacniacz ucieleśniają technologię, która jest wyzwoleńcza i rezydualna. Nie może ona funkcjonować bez fizycznej obecności ludzi, a jej działanie jest przerywane, zakłócone przez hałasy tła, ograniczane ciałem i architektoniczno-środowiskową przestrzenią protestu. Human microphone manifestuje otwartość społeczności - transmisja przekazu werbalnego zależy od ciał otwartych na elementy zewnętrzne. Partycypacja w tej technologii oznacza, że indywidualność protestujących zostaje zdemontowana i owładnięta przez zbiorowość (Kelp-Stebbins, Schifani 2015).

Demokracja jest powszechnie utożsamiana z nagłaśnianiem, dawaniem i posiadaniem głosu. Wydaje się, ze globalne dyskusje na ten temat implikują dwa podstawowe sposoby jego rozumienia. Po pierwsze, liberalna demokracja ufundowana jest na idei, że każdy dorosły obywatel „ma głos”, który może i powinien być wysłuchany. Odnosi się to zwłaszcza do prawa do głosowania, a głosy te są uznawane za funkcjonalnie równe. Ekspresja demokratycznej przynależności wymaga aktywnego uczestnictwa posiadających różne interesy jednostek, które walczą o przestrzeń do mówienia, debatowania i dyskutowania. Akademicy często podkreślają, że użycie języka jest centralne dla praktykowania demokracji poprzez teksty (Habermas 1989), media społecznościowe (Juris 2012: 259-279; Bonilla, Rosa 2015: 4-17), debaty face-to-face (Cody 2011: 37-52) i przemowy (Bate 2009.) Te głosy służą jako metafory politycznej partycypacji.

Drugie skojarzenie z głosem $\mathrm{w}$ demokracji pojawia się w dyskusjach nad polityczną reprezentacją. Ucieleśnia więc pojęcie demokracji reprezentatywnej, w której politycy twierdzą, że reprezentują głosy wielu. Jednak polityczne metafory głosu są często bezcielesne, $\mathrm{z}$ trudem inwokują odniesienia do jego materialności oraz tekstury. W dyskusjach filozoficznych demokracja i metafory politycz- 
nego głosu często odnoszą się do mowy dyskursywnej. Rzadko rozważają inne dźwiękowe formy politycznej wypowiedzi, takie jak okrzyki, kolektywne śpiewanie, hałas czy aktywna cisza, które są tak bardzo charakterystyczne dla demokracji uczestniczącej. W kolektywnych działaniach, takich jak demonstracje i protesty, pojęcie głosu spoczywa nie w pojedynczym głosie mówiącego, ale w masowym i zbiorowym, dzięki czemu przekaz zyskuje na słyszalności (Kunreuther 2018: 1-31). Takie rozumienie głosu urealnia idea wcześniej opisanego ludzkiego mikrofonu, który jest sposobem na niemechaniczną amplifikację głosu, totalnie podważającą jego stechnologizowane, kontrolujące i opresyjne zapośredniczanie (Kelp-Stebbins, Schifani 2015).

Z szerszej perspektywy można postawić pytanie o to, jak brzmi demokracja uczestnicząca. To pytanie jest zainspirowane popularnością studiów krytycznych nad politycznym subiektywizmem przy uwzględnieniu emocji, zmysłów i ciała (Athanasiou 2005: 40-57; 2017; Stoler 2007: 4-20; Manoukian 2010: 237-263; Mazzarella 2010: 697-727; Butler 2015; Cody 2011). Na to pytanie próbuje odpowiedzieć Laura Kunreuther, analizując cztery motywy soniczne obecne w protestach ulicznych na całym świecie: aktywną ciszę, transmisje nagrań lamentu, trąbienie i uderzanie w talerze. Są to motywy, które nie są ani w pełni dyskursywne, ani muzyczne - są jednocześnie takie i takie. Wytwarzają demokratyczny soundscape wymierzony przeciwko codziennym dźwiękom miasta (Kunreuther 2017) oraz zorientowany medialnie - większość wyrafinowanych form dźwiękowego oporu jest produkowana z myślą o jego cyrkulacji w mediach publicznych. $\mathrm{W}$ ten sposób rozprzestrzeniająca się dźwiękowość protestów stymuluje jednocześnie dotąd nieobecne zainteresowanie emocjonalną i cielesną naturą politycznych wydarzeń. Laura Kunreuther podkreśla, że badania nad oporem, władzą, demokracją muszą dziś uwzględniać nierozerwalne połączenie między tym, co racjonalne i afektywne, ideowe i materialne. Innymi słowy chodzi o zadanie pytania o brzmienie demokracji, bo kolektywny głos jest polifonią perspektyw (Kunreuther 2018: 1-31).

Głos rozumiany jako jednocześnie polityczny i performatywny nie odnosi się wyłącznie do mówienia, lecz także do słuchania, słyszenia i bycia słyszalną/słyszalnym. To, w jaki sposób jest używany w trakcie demonstracji, protestów i pikiet, może wiele powiedzieć o tym, jak na różne głosy reagują różni słuchający, czy i na jakich zasadach głosy te są akceptowane lub odrzucane (Lawy 2017: 192-215). Słuchanie/słyszenie/przesłyszenie to efekty tego, w jaki sposób głos jest produkowany. W grę wchodzi użycie języka, tonalność mowy, dosłowna i symboliczna treść mówienia, gesty cielesne i mikroekspresje, które wpływają na legitymizację głosu. Kiedy myślimy o głosie w sposób najbardziej potoczny, myślimy o nim jako komunikatywnym przekazie. W tej formie głos rzeczywiście jest centralny dla życia społecznego i politycznego (Keane 1999: 273). Głos można odnosić także do sprawczości, reprezentacji, władzy i autorytarności. Dalej może być rozpatrywany jako różnorodny i kontekstualny w odniesieniu do zarówno grup, 
jak i jednostek. Jak wyjaśnia Ajrun Appadurai (1988: 17), głos jest problemem mnogości oraz problemem reprezentacji. W antropologii głos często był łączony $\mathrm{z}$ reprezentacjami tekstualnymi, a dyskusję nad tym rozpoczął w latach 80 . XX wieku James Clifford wraz George'em Marcusem (1986). Poza tą debatą głos był łączony z lingwistyczną ekspresją sprawczości, hierarchiami, politykami oraz ekonomiami zmiany (Dinwoodie 1998: 194). Wciąż jednak był rozpatrywany w kontekście jego własności materialnych. Wydaje się więc, że głos jest terminem, który działa na wielu różnych polach. Służy do opisu różnych aspektów życia społecznego i politycznego. W relacji do ruchów społecznych często jest łączony z dążeniem do politycznej rozpoznawalności, równości i politykami tożsamościowymi, ponieważ bywa kluczowy dla zrozumienia walki o prawa choćby osób z niepełnosprawnościami, ruchów feministycznych czy mniejszości etnicznych. W tych przypadkach teoria głosu sięga poza doświadczenia jednostkowe, odnosząc się do kolektywnych i podzielanych doświadczeń istotnych dla jednoczenia członków grup mniejszościowych borykających się z niesprawiedliwością i dyskryminacją. Głos może iść ramię w ramię z myśleniem o dostępie do władzy politycznej. W tym kontekście to zróżnicowanie głosów staje się konieczne, by zapewnić odpowiednie funkcjonowanie demokratycznemu systemowi politycznemu. Potrzeba udzielania głosu różnym grupom jest często centralna dla demokratycznych projektów politycznych (Lawy 2017: 192-215).

Mieć głos to nie tylko podtrzymywać i wysuwać polityczne postulaty, to także klucz do zrozumienia tożsamości, władzy, konfliktu, społecznej pozycji oraz sprawczości (Feld et al. 2004: 341; Weidman 2014: 39). Materialność głosu, tożsamość, polityka nie są od siebie odseparowane, zwłaszcza jeśli rozważymy współczesną dominację polityk tożsamościowych, w których to, kim mówisz, że jesteś, oraz co mówią inni, ma ogromne znaczenie. Grupowe i jednostkowe przynależności i tożsamości bywają powiązane choćby z procesami odzyskiwania ziemi, praw obywatelskich i domagania się równego traktowania. Głos jest sposobem aktorów społecznych na performowanie ich tożsamości oraz użycie własnej sprawczości. W różnych kontekstach głos może różnie brzmieć, zmieniać się i być wieloraki dla pojedynczych aktorów społecznych. Jane H. Hill (1995: 97-147) sugeruje, że nie powinniśmy szukać prawdziwego ,ja" reprezentowanego w jakimkolwiek pojedynczym głosie, bo „ja” znika wśród wielu głosów. Głos używa mowy i gestów. Judith Butler pisze o performatywności aktu mówienia, który inkorporuje otaczającą nas rzeczywistość. Akty mowy składają się ze słów i tonu. To konstelacja znaczenia, sposobu jego dostarczenia, nieintencjonalnego efektu, które muszą być rozpatrywane jako pewien rodzaj całości (Butler 2004: 172). Mówienie jest aktem cielesnym, który wymaga krtani, ust, języka, warg i płuc (Butler 2004: 172). Mówienie przepływa przez ciało, wytwarza je i je prezentuje (Merleau-Ponty 1962). Społeczna i polityczna artykulacja spoczywa w animowanej mowie, która używa ciała po to, by wywołać odpowiednią, pożądaną sytuację, kiedy to mówiący ma być słyszany i słuchany. Maurice Merleau-Ponty podkreślał, że mówione słowa 
nie są tylko przekazem, ponieważ na akt mówienia składają gesty ekspresywne współtworzące sposoby bycia (Merleau-Ponty 1962: 150). Głos, jako coś, co jest słyszane, musi być też rozpatrywany w szerszym kontekście społecznym. Ciało jest zintegrowane z głosem i pewne jego rodzaje są bardziej słyszalne w przestrzeni publicznej niż inne.

Koncepcja głosu może otwierać nowy, choć niekoniecznie krzepiący, sposób rozumienia choćby strajków, manif i czarnych protestów, jakie są organizowane w Polsce od 2016 roku. Robin James (2015) uważa, że słyszalność kobiecych i feministycznych głosów służy jako mylący dowód na to, że patriarchat się skończył, ponieważ czyni go jedynie niewidocznym. Takie rozumienie słyszalności głosu możliwe jest przy zastosowaniu kategorii sophrosyne. Sophrosyne to pojęcie (często tłumaczone jako „moderacja”), które odgrywało istotną rolę w starożytnej Grecji w odniesieniu do koncepcji harmonii muzycznej odczytywanej jako paralelna do porządku społecznego. Słowo to spotykane już u Homera, określa też zdrowy rozsądek, „dobry rozum”, który bogowie, jeśli chcą, mogą człowiekowi odebrać lub przywrócić. W VII i VI wieku p.n.e. nabiera nowego znaczenia - rozwagi, panowania nad sobą, umiaru i powściągliwości.

Starożytni Grecy sądzili, że głosy kobiet są niemoderacyjne, nieuporządkowane i nieumiarkowane, gdy osiągają nadmierną częstotliwość. Kobieca sophrosyne była synonimem kobiecego posłuszeństwa. O ile męska mowa była odczytywana jako logiczna i zgodna z kosmicznym porządkiem, o tyle mowa kobiet - jako zakłócająca i dezorganizująca. O ile w harmonijnym społeczeństwie greckim głos ten nie istniał, o tyle we współczesnych neoliberalnych demokracjach włącza się jego określoną ilość, lecz jest to głos o kontrolowanej jakości i zawartości (Carson 1995: 119-142). Krytycy demokratycznie rozumianego głosu wskazują, że deklaracje udzielania, uwalniania i odzyskiwania głosu są iluzoryczne. Okazuje się, że głos ten często zawodzi, gdy staje w obliczu problemu władzy. Udzielanie głosu bywa selektywne, a jego wzmacnianie raczej podtrzymuje nierównowagę, niż ją znosi. Innymi słowy partycypacja i inkluzja rozumiane jako dopuszczenie do głosu bywają sterowane i służą ukryciu faktycznych nierówności.

Zbyt wiele feministycznego dźwięku nie jest na miejscu, a hałas wytwarzany przez kobiety musi podlegać moderacji, głównie w znaczeniu normalizacji i kontroli jego dynamiki. Istnieje przekonanie, że głosy kobiet zwracają uwagę na trwający patriarchat i mizoginię zbyt głośno. Sara Ahmed wyjaśnia, że słowa takie jak na przykład „seksizm” są słyszane jako szorstkie, ponieważ nazywają to, co zniknęło z pola widzenia. Głosy, które mówią o trwającej nierówności płci, opresji i dyskryminacji, są obciążone tymi samymi wadami, które przypisuje się nadmiernie zgłośnionej i skompresowanej muzyce (Ahmed 2014). Taki rodzaj muzyki wedle Suhasa Sreedhara (2007) jest potocznie postrzegany jako zaprzepaszczenie jej „naturalności”. W konsekwencji protestujące kobiety uznaje się za występujące przeciwko naturalnej harmonii społecznej. Wydaje się, że w społeczeństwie postfeministycznym ludzie, którzy uważają, że seksizm i nierówność 
płci istnieją, tkwią w pozbawionym ekspresyjności zakresie. Podobnie jak w muzyce, brak dynamiki powoduje, że dźwięk staje się hałasem. To tak, jakby ktoś cały czas krzyczał zamiast mówić. W rezultacie oddziaływanie takiego głosu staje się męczące i nieczytelne. Głośna muzyka jest uznawana za nieefektywną i niezdrową dla tych, którzy są wystawieni na jej działanie. Podobnie jest $\mathrm{z}$ aktywistkami, które są uznawane za zagrażające, niecywilizowane, agresywne, wystawiające na szwank proces zmiany społecznej, nadszarpujące prawidłową kondycję tego, co publiczne. Dziennikarka Michelle Goldberg określa głosy feministek jako toksyczne (2014).

Współczesna koncepcja harmonii społecznej nie bazuje na greckiej teorii muzyki, ale na akustyce. Alex Pentland w swojej społeczno-matematycznej koncepcji, za pomocą której wyjaśnia relacje między przepływem informacji a ludzkim zachowaniem, pokazuje, że zachowania jednostkowe oraz grupowe są podyktowane wzorami, które wyłaniają się jako sygnały $\mathrm{z}$ hałaśliwego strumienia danych na takich samych zasadach, jak harmonie i partie wyłaniają się z częstotliwości dźwięków (Pentland 2014). W tym kontekście głośne feministyczne głosy mogą być postrzegane jako zaburzające zastaną dynamikę przepływu obowiązujących idei i zasad. Robin James (2015) twierdzi, że głosy kobiet raczej wzmacniają patriarchalny porządek. Kiedy przekształcają się w hałas, są odbierane jako nadmiernie głośne i w tym samym czasie patriarchat wzmacnia swoje własne częstotliwości (choćby w formie tzw. hejtu czy nacjonalistycznych, ultrakonserwatywnych bądź ultrakatolickich kontrmanifestacji), tak aby pozorna wielość głosów znalazła się na powrót na odpowiednim poziomie.

Zaproponowany przeze mnie przegląd ma za zadanie zasygnalizować potencjał tkwiący w refleksji nad pozawizualnymi ekspresjami oporu i sprzeciwu społecznego. Temat dźwiękowego wymiaru protestów, demonstracji i rebelii można by kontynuować, wskazując na rolę i zmieniającą się funkcję protest songów, zjawisko internetowej i społecznościowej dystrybucji dźwięków manifestacji, tworzenia na ich bazie muzycznych emanacji i reinterpretacji, niekiedy całych soundtracków i playlist, jak stało się to w przypadku dźwięków Euromajdanu (Morozova 2015). Dalej można rozwijać dyskusję w kierunku ekologii akustycznej i demokratycznych, miejskich soundscapeów, rozważać nad metodologiami badań nad dźwiękiem protestów czy przyglądać się potrzebie stymulowania i projektowania dźwięku protestów. Ten ostatni aspekt wydaje się szczególny. Edyta Jarząb, artystka dźwiękowa, animatorka głosu, wieloletnia dokumentalistka demonstracji, która organizuje warsztaty i rozgrzewki przed demonstracjami ulicznymi, doszła do niepokojącego wniosku. Zauważyła, że głos protestujących, których można określić jako nacjonalistycznych i konserwatywnych, jest dużo silniejszy niż ludzi choćby broniących konstytucji, wolnych mediów czy praw reprodukcyjnych. Jest to głos wysoce zsynchronizowany, stanowiący szczególny ornament władzy, wyraźnie wykluczający indywidualizm i pluralizm („kto nie idzie z nami, jest przeciwko nam") (Jarząb 2017a, 2017b). Podobną obserwację czyni Justyna Drath: 
nasze protesty też są najczęściej ponure i zacięte. Gniew bez jednoczesnej opowieści o alternatywie jest bardzo męczący. Antyrasistowskie manifestacje wpadają niekiedy w ten sam schemat akademii w słusznej sprawie, na której nie potrafimy się zdobyć na naturalność. Narzekając na zagarnianie wszystkich świąt państwowych przez nacjonalistyczny przekaz, nie potrafimy stworzyć języka, którym opowiemy o alternatywnej rzeczywistości i nie będziemy jedynie kwestionować tej, która jest wokół. Skoro nie potrafimy o niej nawet marzyć i o niej zaśpiewać, trudno też nam będzie ją sobie wyobrazić. Śpiewanie natomiast leczy z przełamywania wstydu i cynizmu, a patosowi nadaje rys autentyczności. Jeśli nie nauczymy się śpiewać własnych piosenek, nie będziemy w stanie uczestniczyć w prawdziwych rytuałach (Drath 2017).

\section{Bibliografia}

Ahmed S.

2014 Dated Feminists, „Feministkilljoys”, https://feministkilljoys.com/2014/04/08/ dated-feminists/ (dostęp: 30.07.2018).

"American Ethnologist"

2012, no.1(39), s. 1-233.

2014, no. 3(41), s. 405-616.

2017 , no. 2(44), s. 187-391.

"Anthropology Now"

2017, no. 1(9), s. 1-139.

Appadurai A.

1988 Introduction: Place and Voice in Anthropological Theory, „Cultural Anthropology", no. 1(3), s. 16-20.

Athanasiou A.

2005 Reflections on the Politics of Mourning: Feminist Ethics and Politics in the Age of Empire, „Historein”, vol. 5, s. 40-57.

2017 Agonistic Mourning: Political Dissidence and the Women in Black, Edinburgh.

Attali J.

1985 Noise: The Political Economy of Music, Minneapolis.

Baaz M., Lilja M., Vinthagen S.

2017 Resistance Studies as an Academic Pursuit, „Journal of Resistance Studies”, no. 1(3), s. 10-20.

Bartosiewicz A.

2017 Poczuj siłę kobiet! Chór Czarownic, „Artaktywnie - kulturalny blog Anny Bartosiewicz", 20.11.2017, https://artaktywnie.wordpress.com/2017/11/20/poczuj-silekobiet-chor-czarownic-piesni-czarownicy/ (dostęp: 30.07.2018).

Bate B.

2009 Tamil Oratory and the Dravidian Aesthetic: Democratic Practice in South India, New York.

Bednarz N.

2017 Donośny głos polskich kobiet... z siedzibq w Poznaniu, „Freshmag”, 28.10.2017, http://freshmag.pl/magazyn/muzyka/chor-czarownic (dostęp: 30.07.2018).

Bennett L., Segerberg A.

2012 The Logic of Connective Action, „Information, Communication \& Society”, no. 5(15), s. 739-768. 
Boas F.

1889 On Alternating Sounds, „American Anthropologist”, vol. 2(1), s. 47-54.

1940 Race, Language and Culture, New York.

Bonilla Y., Rosa J.

2015 \#Ferguson: Digital Protest, Hashtag Politics, and the Racial Politics of Social Media in the United States, „American Ethnologist”, no. 1(42), s. 4-17.

Born G. (ed.)

2013 Music, Sound, and Space: Transformations of Public and Private Experience, Cambridge.

Borowska A.

2017 Usłyszcie ich krzyk, czyli o hałasie wokół inwazji na Czechosłowację w 1968 roku, „Glissando”, nr 30.

Bourdieu P.

1998 On Television, transl. P. Parkhurst Ferguson, New York.

Bull M. (ed.)

2013 Sound Studies, London.

Butler J.

2004 Undoing Gender, New York.

2015 Notes Toward a Performative Theory of Assembly, Cambridge.

Carson A.

1995 The Gender of Sound [w:] A. Carson, Glass, Irony and God, Davenport, s. 119142.

Classen C.

1993 Worlds of Sense: Exploring the Senses in History and across Cultures, London.

Clifford J., Marcus G.

1986 Writing Culture: The Poetics and Politics of Ethnography, Berkeley.

Cody F.,

2011 Publics and Politics, „Annual Review of Anthropology”, vol. 40, s. 37-52.

Corbin A.

1995 Time, Desire, and Horror: Towards a History of the Senses, Cambridge.

Czarnecka A.

2017 Raport rewolucja - i co dalej? Ruchy kobiece w poszukiwaniu nowych form polityczności w 2017, Warszawa, https://czarnacka.blog.polityka.pl/wp-content/uploads/ 2018/05/FIJN-rewolucja-i-co-dalej-2017.pdf (dostęp: 30.07.2018).

Darnton R.

1991 The Great Cat Massacre and other Episodes in French Cultural History, Harmondsworth.

Davis N.Z.

1973 The Reasons of Misrule: Youth Groups and Charivaris in Sixteenth-Century France, „Past and Present”, vol. 50, s. 41-75.

Deaville J.

2011 The Envoicing of Protest: Occupying Television News through Sound and Music, „Journal of Sonic Studies”, no. 1(3), http://journal.sonicstudies.org/vol03/nr01/a05 (dostęp: 30.07.2018).

della Porta D., Mattoni A. (eds.)

2014 Spreading Protest: Social Movements in Times of Crisis, Colchester. 
Demonstracja „Wolne Polki - Wolna Polska. Wszyscy za jedna, jedna za wszystkich”, 2017 Federacja na Rzecz Kobiet i Planowania Rodziny, 25.09.2017, http://federa.org. pl/demonstracja-wolne-polki-wolna-polska-wszyscy-za-jedna-jedna-za-wszystkich/ (dostęp: 30.07.2018).

Denisoff R.S.

1970 Protest Songs: Those on the Top Forty and Those of the Streets, „American Quarterly", no. 4(22), s. 807-823.

Dinwoodie D.W.

1998 Authorizing Voices: Going Public in an Indigenous Language, „Cultural Anthropology", no. 2(13), s. 193-223.

Dłużewska E.

2017 „Wolność, równość, wyobraźnia”. Forum Przyszłości Kultury $w$ ten weekend w Warszawie, „Gazeta Wyborcza. Warszawa”, 16.11.2017, http://wyborcza.pl/ 7,75410,22647781,wolnosc-rownosc-wyobraznia-forum-przyszlosci-kultury-w.html (dostęp: 30.07.2018).

Dohnal W.

2017 „Czarny poniedziałek” $i$ „Łańcuch światła”. O infrapolitycznych formach oporu społecznego [w:] W. Dohnal, W. Kuligowski, J. Schmidt (red.), Kulturowe kody - etnologiczne klucze. Szkice dedykowane doktorowi Jackowi Bednarskiemu, Poznańskie Studia Etnologiczne, Poznań, nr 21, s. 89-108.

Doroszkiewicz J.

2018 Dni Sztuki Współczesnej 2018. Kino Forum. Chór Czarownic - industrialny i feministyczny punk, „Poranny.pl”, 28.05.2018, http://www.poranny.pl/kultura/koncerty/a/ dni-sztuki-wspolczesnej-2018-kino-forum-chor-czarownic-industrialny-i-feministyczny-punk-zdjecia-wideo,13211669/ (dostęp: 30.07.2018).

Drajewski S.

2017 Od czarownicy z Chwaliszewa do... czarnego protestu - recenzja spektaklu „Pieśni czarownic”, „Głos Wielkopolski”, 22.05.2017, http://www.gloswielkopolski.pl/ kultura/a/od-czarownicy-z-chwaliszewa-do-czarnego-protestu-recenzja-spektaklupiesni-czarownic, 12100802/ (dostęp: 30.07.2018).

Drath J.

2017 W poszukiwaniu utraconego głosu, „Krytyka Polityczna”, 18.06.2017, http://krytykapolityczna.pl/kultura/muzyka/w-poszukiwaniu-utraconego-glosu/ (dostęp: 30.07.2018).

Drozdowski R.

2017 Jak i po co badać wizualność protestów społecznych?, „Czas Kultury”, nr 4(195), s. $21-26$.

Erlmann V.

2004 But What of the Ethnographic Ear? Anthropology, Sound, and the Senses [w:] V. Erlmann (ed.), Hearing Cultures: Essays on Sound, Listening and Modernity, Oxford, s. $1-20$.

Eyerman R., Jamison A.

1998 Music and Social Movements: Mobilizing Traditions in the Twentieth Century, Cambridge.

Feld S.

1982 Sound and Sentiment: Birds, Weeping, Poetics and Song in Kaluli Expression, Philadelphia.

1996 Waterfalls of Song: An Acoustemology of Place Resounding in Bosavi, Papua New

Guinea [w:] Senses of Place, S. Feld, K. Basso (eds.), Santa Fe, s. 91-136. 
Feld S. et al.

2004 Vocal Anthropology: From Music of Language to the Language of Song [w:] A. Duranti (ed.), A Companion to Linguistic Anthropology, Malden, s. 321-346.

Fosshagen K. (ed.)

2014 Arab Spring. Uprisings, Powers, Interventions, „Critical Interventions: A Forum for Social Analysis", vol. 14, New York-Oxford.

Furmage S., Rubin J.S.

2015 \#BlackLivesMatter: Anthropologists on Protest, Policing and Race-Based Violence, „AnthroPod: The SCA Podcast, Cultural Anthropology website”, 18.11.2015, https:// culanth.org/fieldsights/752-blacklivesmatter-anthropologists-on-protest-policingand-race-based-violence (dostęp: 30.07.2018).

Goldberg M.

2014 Feminism's Toxic Twitter Wars, „The Nation”, https://www.thenation.com/article/ feminisms-toxic-twitter-wars/ (dostęp: 30.07.2018).

Gopinath S., Stanyek J. (eds.)

2014 The Oxford Handbook of Mobile Music Studies, vol. 1/2, Oxford.

Graeber D.

2013 The Democracy Project: A History, A Crisis, A Movement, New York.

Graff A., Korolczuk E.

2016 Rewolucja rewolucja, ale winny jest gender, „OKO Press”, 09.08.2016, https://oko. press/papiez-franciszek-rewolucja-rewolucja-winnygender/ (dostęp: 30.07.2018).

Grzebalska W.

2016 Why the War on 'Gender Ideology' Matters - and not just to Feminists, „Visegrad Insight”, 05.03.2016, http://visegradinsight.eu/why-the-war-ongender-ideology-matters-and-not-just-to-feminists/ (dostęp: 30.07.2018).

Habermas J.

1989 The Structural Transformation of the Public Sphere, transl. T. Burger, F. Lawrence, Cambridge.

Helmreich S.

2010 Listening Against Soundscapes, „Anthropology News”, no. 9(51), s. 10.

2016 Gravity's Reverb: Listening to Space-Time, or Articulating the Sounds of Gravitational-Wave Detection, „Cultural Anthropology”, no. 4(31), s. 464-492.

Hewitt N. (ed.)

2010 No Permanent Waves: Recasting Histories of U.S. Feminism, New Brunswick.

Hill J.H.

1995 The Voices of Don Gabriel: Responsibility and Self in a Modern Mexicano Narrative [w:] D. Tedlock, B. Mannheim (eds.), The Dialogic Emergence of Culture, Urbana, s. 97-147.

Holston J.

2013 Come to the Street: Urban Protest, Brazil 2013, „Hot Spots, Cultural Anthropology website", 20.12.2013, https://culanth.org/fieldsights/458-come-to-the-street-urbanprotest-brazil-2013 (dostęp: 30.07.2018).

Howes D. (ed.)

1991 The Varieties of Sensory Experience: A Sourcebook in the Anthropology of the Senses, Toronto.

Ingold $\mathrm{T}$.

2007 Against Soundscape [w:] E. Carlyle (ed.), Autumn Leaves: Sound and the Environment in Artistic Practice, Paris, s. 10-13. 
2011 Four Objections to the Concept of Soundscape [w:] T. Ingold, Being Alive: Essays on Movement, Knowledge and Description, London-New York, s. 136-139.

Jakobson R.

1987 Language in Literature, Cambridge, MA.

James R.

2015 Gendered Voices and Social Harmony, „Sound Studies Blog”, https://soundstudiesblog.com/2015/03/09/gendered-voices-and-social-harmony/ (dostęp: 30.07.2018). Jarząb E.

2017a Akustyczny dziennik demonstrantki, „Glissando”, nr 30.

2017b Strajkuj i daj głos!, „Glissando”, nr 30.

Jaśkiewicz H.

2017 Czarownice z Chwaliszewa, „TeczowyPoznan.pl”, http://teczowypoznan.pl/czarownice-z-chwaliszewa/ (dostęp: 30.07.2018).

Jourabchi D. et al.

2016 Warsound/Warszawa, Warszawa.

Jurgenson N.

2011 Occupy Audio: The Soundscape of Protests, „The Atlantic”, http://www.theatlantic. com/technology/archive/2011/11/occupy-audio-the-soundscape-of-protests/249123/ Juris J. (dostęp: 30.07.2018).

2012 Reflections on \#Occupy Everywhere: Social Media, Public Space, and Emerging Logics of Aggregation, „American Ethnologist”, no. 2(39), s. 259-279.

Juris J., Razsa M.

2012 Occupy, Anthropology, and the 2011 Global Uprisings, „Hot Spots, Cultural Anthropology website", https://culanth.org/fieldsights/63-occupy-anthropology-andthe-2011-global-uprisings (dostęp: 30.07.2018).

Kapelański M.

2015 „Koncerty garków i patelek” podczas wielkich demonstracji studenckich 2012 r. $w$ Montrealu. Sprawozdanie z publicznego, interpersonalnego i osobistego doświadczenia pejzażu dźwiękowego, „Audiosfera. Koncepcje - Badania - Praktyki”, nr 2, s. 18-28.

Karlberg E.

2017 Is it the Swan Song of Patriarchy, or the Beginning of a New Ice Age? Interview with Agnieszka Graff and Elżbieta Korolczuk, „Baltic Worlds”, no. 4, s. 4-9.

Katz M.

2010 Capturing Sound: How Technology Has Changed Music, Berkeley.

Kelp-Stebbins K., Schifani A.M.

2015 The Medium is the Masses: Embodied Amplification, Urban Occupation, „Media Fields Journal", no. 9, http://www.mediafieldsjournal.org/the-medium-is-the-masses/2015/8/21/the-medium-is-the-masses-embodied-amplification-urban-occupa. html (dostęp: 30.07.2018).

Koefood M.

2017 Accessing the Backstage: Ethnographic Research Methods in Resistance Studies, „Journal of Resistance Studies”, no. 2(3), s. 19-41.

Korolczuk E.

2016 Mass Mobilization against the Ban on Abortion in Poland, „Baltic Worlds”, 05.04.2016, http://balticworlds.com/mass-mobilization-against-theban-on-abortion/ (dostęp: 30.07.2018). 
2018 Czarny Piątek jako pożegnanie z Kościołem, „Krytyka Polityczna”, 26.03.2018, http://krytykapolityczna.pl/kraj/czarny-piatek-jako-pozegnanie-z-kosciolem/ (dostęp: 30.07.2018).

Kowalewski M.

2017 Architektura przestrzeni politycznej: plac Solidarności w Szczecinie, „Czas Kultury", nr 4(195), s. 42-49.

Krzemiński I.

2017 Narodowo-katolicka mowa o Polsce. Obrońcy krzyża przed Pałacem Prezydenckim, „Czas Kultury”, nr 4(195), s. 50-64.

Kubisa J.

2016 Odzyskajmy Polskę dla kobiet!, „Krytyka Polityczna”, 10.10.2016, http://krytykapolityczna.pl/kraj/odzyskajmy-polske-dla-kobiet/2016/ (dostęp: 30.07.2018).

Kuligowski W., Pomieciński A. (red.)

2012 Oblicza buntu. Praktyki i teorie sprzeciwu w kulturze współczesnej, Poznań.

Kunreuther L.

2017 Democratic Soundscapes, „Avery Review”, no. 21, http://averyreview.com/issues/21/democratic-soundscapes (dostęp: 30.07.2018).

2018 Sounds of Democracy: Performance, Protest, and Political Subjectivity, „Cultural Anthropology", no. 1(33), s. 1-31.

Lawy J.R.

2017 Theorizing Voice: Performativity, Politics and Listening, „Anthropological Theory”, no. 2(17), s. 192-215.

Leniarska Z.

2016 \#czarnyprotest: bez praw kobiet nie ma demokracji, „Wysokie Obcasy - Gazeta Wyborcza”, 05.10.2016, http://www.wysokieobcasy.pl/wysokie-obcasy/7,53662,20825 876,czarnyprotest-bez-praw-kobiet-nie-ma-demokracji.html (dostęp: 30.07.2018).

Lévi-Strauss C.

1970 The Raw and the Cooked: Introduction to a Science of Mythology, vol. 1, transl. J. Weightman, D. Weightman, London.

1973 From Honey to Ashes: Introduction to a Science of Mythology, vol. 2, transl. J. Weightman, D. Weightman, New York.

Lichota P.

2016 Tradycja hałasu w sztuce dźwięku, Poznań.

Majewska E.

2016 Słaby opór i siła bezsilnych. \#CzarnyProtest w Posce 2016, „Praktyka Teoretyczna”, 10.11.2016, http://www.praktykateoretyczna.pl/tag/czarny-protest/ (dostęp: 30.07.2018).

Makley Ch.

2015 The Sociopolitical Lives of Dead Bodies: Tibetan Self-Immolation Protest as Mass Media, „Cultural Anthropology”, no. 3(30), s. 448-476.

Manoukian S.

2010 Where Is This Place? Crowds, Audio-vision, and Poetry in Postelection Iran, „Public Culture”, no. 2(22), s. 237-263.

Marzec L.

2017 Gorzka zemsta, słodka kara, „Czas Kultury.pl. Czytanki”, 05.06.2017, http://czas kultury.pl/czytanki/gorzka-zemsta-slodka-kara/ (dostęp: 30.07.2018). 
Maślanka T., Wiśniewski R. (red.)

2015 Kultury kontestacji: dziedzictwo kontrkultury i nowe ruchy społecznego sprzeciwu, Warszawa.

Mazur N.

2016 Czarny protest i jego konsekwencje. Poznanianki stworzyly Chór Czarownic. Czy to Średniowiecze?, „Gazeta Wyborcza. Magazyn Poznański”, 28.10.2016, http://poznan.wyborcza.pl/poznan/1,105531,20902619,czarny-protest-i-jego-konsekwencjepoznanianki-stworzyly-chor.html (dostęp: 30.07.2018).

Mazzarella W.

2010 The Myth of the Multitude, or Who's Afraid of the Crowd?, „Critical Inquiry”, no. 4(36), s. 697-727.

McCaugan M., Balance L.

2009 Our Noise: The Story of Merge Records, the Indie Label That Got Big and Stayed Small, Chapel Hill.

Merleau-Ponty M.

1962 Phenomenology of Perception, transl. C. Smith, London.

Michnik A.

2011, Przenikanie przestrzeni - o Andrzeju Mitanie i projekcie Ptaki, „Glissando”, nr 18. Mintz J.R.

1997 Carnival Song and Society: Gossip, Sexuality, and Creativity in Andalusia, Oxford. Misiakiewicz S.

2017 „Pieśni Czarownicy”, „Dzielnice Magazine”, 27.03.2017, http://www.dzielnicewroclawia.pl/piesni-czarownicy-recenzja/ (dostęp: 30.07.2018).

Molina A.G., Cossette J.

2016 Election's Reverb: An Interview with Stefan Helmreich, „Dialogues, Cultural Anthropology website”, 16.12.2016, https://culanth.org/fieldsights/1011-election-sreverb-an-interview-with-stefan-helmreich (dostęp: 30.07.2018).

Morozova L.

2015 Sounds of Maidan, transl. K. Karmnik, „Glissando”, nr 26, http://glissando.pl/en/ text/sounds-of-maidan/ (dostęp: 30.07.2018).

Narkowicz K.

2016 Czarny Protest: How Polish Women Took to the Streets, „OpenDemocracy”, 10.10.2016, https://www.opendemocracy.net/can-europemake-it/kasia-narkowicz/ czarny-protest-how-polish-women-took-to-streets (dostęp: 30.07.2018).

Nodzyńska P.

2018, „Czarny piątek” w Zielonej Górze: „Kobieta to nie inkubator”, „Gazeta Wyborcza. Zielona Góra”, 23.03.2018, http://zielonagora.wyborcza.pl/zielonagora/7,35182,23183 371,czarny-piatek-w-zielonej-gorze-kobieta-to-nie-inkubator-mnostwo.html (dostęp: 30.07.2018).

Novak D.

2015 Noise [w:] D. Novak, M. Sakakeeny (eds.), Keywords in Sound, Durham-London, s. $125-138$.

Novak D., Sakakeeny M.

2015 Introduction [w:] D. Novak, M. Sakakeeny (eds.) Keywords in Sound, DurhamLondon, s. 1-11.

Nowicka-Franczak M.

2017 Dylematy (nie)zaangażowanego badania dyskursu w czasach społeczno-politycznego przesilenia, „Czas Kultury”, nr 4(195), s. 12-20. 


\section{O’Brien M.S.}

2013 This is What Democracy Sounds Like: Live and Mediated Soundscapes of the Wisconsin Uprising, „Music \& Politics”, no. 2(7), https:/quod.lib.umich. $\mathrm{edu} / \mathrm{m} / \mathrm{mp} / 9460447.0007 .204 /$--this-is-what-democracy-sounds-like-live-andmediated?rgn=main;view=fulltext (dostęp: 30.07 .2018$)$.

Pasieka A.

2015 Opór, dominacja i teoria społeczna na przełomie XX i XXI wieku [w:] A. Pasieka, K. Zielińska (red.), Opór i dominacja. Antologia tekstów, Kraków, s. 7-29.

Pentland A.

2014 Social Physics: How Good Ideas Spread-the Lessons from a New Science, London. Pezda A.

2017 Rock opera. Halka rządzi!, „Uroda Życia”, http://urodazycia.pl/kobietykobietom/ bohaterki/ewa_lowzyl.pdf (dostęp: 30.07.2018).

Picker J.

2003 Victorian Soundscapes, New York.

Pistrick E., Cyril I.

2013 Landscapes, Soundscapes, Mindscapes: Introduction, „Ethnografica”, no. 3(17), s. $1-11$.

Pitt-Rivers J.

1961 The People of the Sierra, Chicago.

Podemski K.

2017 Manifestacje w polskiej kulturze politycznej, „Czas Kultury”, nr 4(195), s. 6-11.

Rancew-Sikora D., Steciąg M.

2017 „Niech się bawią”? O związkach radykalności z karnawałem na demonstracjach publicznych kobiet, „Czas Kultury”, nr 4(195), s. 27-34.

Reichel-Dolmatoff G.

1971 Amazonian Cosmos: The Sexual and Religious Symbolism of the Tukano Indians, Chicago.

Reynolds S.

2007 Bring the Noise, London.

Rose T.

1994 Black Noise, Hanover.

Roy W.G.

2010 Reds, Whites, and Blues: Social Movements, Folk Music, and Race in the United States, Princeton.

Sahera K., Cetina M.

2016 Music and Performance as Sonic Acts of Political Struggle; Counter-Political Soundscapes in Urban Realm, „Sociology Study”, no. 6(6), s. 378-391.

Sapir E.

1949 Selected Writings in Language [w:] D.G. Mandelbaum (ed.), Culture and Personality, Berkeley.

Sasinowski A.

2016 Kolejna odsłona Czarnego protestu, „Kurier Szczeciński”, 23.10.2016, https://24kurier.pl/aktualnosci/wiadomosci/kolejna-odslona-czarnego-protestu/ (dostęp: 30.07.2018).

Schafer R.M.

1977 The Tuning of the World, New York. 
Schlichter A.

2011 Do Voices Matter? Vocality, Materiality, Gender Performativity, „Body \& Society”, no. 1(17), s. 31-52.

Schulze H.

2012 Jonathan Sterne on Sonic Protest in Canada, „Sound Studies Lab”, http://www. soundstudieslab.org/jonathan-sterne-on-sonic-protest-in-canada/ (dostęp: 30.07.2018).

Schwartz H.

2011 Making Noise: From Babel to the Big Bang and Beyond, New York.

Smith B.R.

1999 The Acoustic World of Early Modern England, Chicago.

"Social Anthropology"

2016, no. 2(24), s. 137-272.

Sreedhar S.

2007 The Future of Music. Part One: Tearing Down the Wall of Noise, „IEEE Spectrum”, https://spectrum.ieee.org/computing/software/the-future-of-music (dostęp: 30.07.2018).

Sterne J.

2012 mp3: The Meaning of a Format, Durham.

Stoler A.L.

2007 Affective States [w:] D. Nugent, J. Vincent (eds.), A Companion to Anthropology of Politics, Malden, s. 4-20.

Stoller P.

1989 The Taste of Ethnographic Things: The Senses in Anthropology, Philadelphia.

2016 The Anthropology of Trump: Myth, Illusion and Celebrity Culture, „Huffpost”, 03.02.2016, https://www.huffingtonpost.com/paul-stoller/the-anthropology-of-trump b_9366242.html (dostęp: 30.07.2018).

2017 More on the Anthropology of Trump, „Anthropology Now”, no. 1(9), s. 58-60.

Suisman D., Strasser S. (eds.)

2009 Sound in the Age of Mechanical Reproduction, Philadelphia.

Sutkowski M.

2017 Nam się zaczęło pod dupa palić... Kim sq organizatorki czarnego protestu?, „Krytyka Polityczna”, 26.05.2017, http://krytykapolityczna.pl/kraj/nam-sie-zaczelo-poddupa-palic-kim-sa-organizatorki-czarnego-protestu/ (dostęp: 30.07.2018).

Sztymelska J.

2017 Czarny wtorek w Tomaszowie Mazowieckim, https://www.nasztomaszow.pl/otomaszowie/czarny-wtorek-w-tomaszowie-mazowieckim/ (dostęp: 30.07.2018).

Ślosarski B.

2017 Czarne skrzynki i Czarny Protest. O roli artefaktów w mobilizacjach społecznych, „Czas Kultury”, nr 4(195), s. 35-41.

Thompson E.P.

1991 Rough Music [w:] E.P. Thompson, Customs in Common, New York, s. 467-538.

Thorkelson E.

2016 The Infinite Rounds of the Stubborn: Reparative Futures at a French Political Protest, „Cultural Anthropology”, issue online, 28 November 2016, https://anthrosource. onlinelibrary.wiley.com/doi/abs/10.14506/ca31.4.03 (dostęp: 30.07.2018).

Tyszka J.

2017 Czarownice dają czadu, „teatralny.pl”, 14.06.2017, http://teatralny.pl/recenzje/ czarownice-daja-czadu,2012.html (dostęp: 30.07.2018). 
„Visual Anthropology”

2016, no. 3(29), s. 205-330.

Weidman A.

2014 Anthropology and Voice, „Annual Review of Anthropology”, vol. 43, s. 37-51.

Wieczorkiewicz P.

2018 Strajk na Dzień Kobiet. Na rondzie $w$ centrum Warszawy stanie pomnik, „Gazeta Wyborcza. Warszawa”, 08.03.2018, http://warszawa.wyborcza.pl/ warszawa/7,54420,23114393,strajk-na-dzien-kobiet-na-rondzie-w-centrum-warszawy-stanie.html (dostęp: 30.07.2018).

Wodecka D.

2016 Czarny protest. Marta Lempart: Ten rząd dalej nie pojedzie - wywiad z Marta Lempart, „Gazeta Wyborcza. Magazyn”, 08.10.2016, http://wyborcza.pl/ magazyn/1,124059,20806433,czarny-protest-marta-lempart-ten-rzaddalej-nie-pojedzie.html (dostęp: 30.07.2018).

Woodruff J.

2014 A Musical Analysis of the People's Microphone: Voices and Echoes in Protest and Sound Art and Occupation 1 for String Quartet, Pittsburgh.

Yiakoumaki V.

2011 Contesting Histories of Greek Student Protest, or the Debate on „Open” and „Closed” Universities, „Hot Spots, Cultural Anthropology website”, 26.11.2011, https://culanth. org/fieldsights/248-contesting-histories-of-greek-student-protest-or-the-debate-onopen-and-closed-universities (dostęp: 30.07.2018).

Yıldırım U., Navaro-Yashin Y.

2013 An Impromptu Uprising: Ethnographic Reflections on the Gezi Park Protests in Turkey, „Hot Spots, Cultural Anthropology website”, 31.11.2013, https://culanth.org/ fieldsights/391-an-impromptu-uprising-ethnographic-reflections-on-the-gezi-parkprotests-in-turkey (dostęp: 30.07.2018).

Żmijewska M.

2018 Śpiewające czarownice i weselne poprawiny. Mocny finał Dni Sztuki Współczesnej, „Gazeta Wyborcza. Białystok”, 28.05.2018, http://bialystok.wyborcza.pl/bialystok/ 7,35241,23467511,spiewajace-czarownice-i-weselne-poprawiny-final-dni-sztuki.html (dostęp: 30.07.2018).

Źródła internetowe

https://www.anthro.ox.ac.uk/asa-2018 (dostęp: 30.07.2018).

https://citiesandmemory.com/ (dostęp: 30.07.2018).

https:/www.facebook.com/events/1666165643698900/?active_tab=discussion(dostęp: 30.07.2018).

https://www.facebook.com/events/968921066552964/?active_tab=discussion (dostęp: 30.07.2018).

http://www.inspirator-polska.pl/aktywator-kultura-poznan/ (dostęp: 30.07.2018).

http://kultura.poznan.pl/mim/kultura/news/relacje-recenzje-opinie,c,9/bliscy-nieznajomi-glos-choru,106073.html (dostęp: 30.07.2018).

https://www.lemonde.fr/politique/article/2018/06/01/marine-le-pen-annonce-que-le-frontnational-devient-rassemblement-national_5308450_823448.html (dostęp: 30.07.2018). http://resistancestudies.org/ (dostęp: 30.07.2018).

http://resistance-journal.org/ (dostęp: 30.07.2018). 